\title{
Article \\ Highly Photoactive Titanium Dioxide Supported Platinum Catalyst: Synthesis Using Cleaner Ultrasound Approach
}

\author{
Shital B. Potdar ${ }^{1}\left(\mathbb{D}\right.$, Chao-Ming Huang ${ }^{2, *}$, BVS Praveen $^{3}{ }^{\mathbb{D}}$, Sivakumar Manickam ${ }^{4}$ and Shirish H. Sonawane ${ }^{1, *}$ \\ 1 Department of Chemical Engineering, National Institute of Technology Warangal, \\ Warangal 506004, Telangana, India; shital@student.nitw.ac.in \\ 2 Green Energy Technology Research Center, Department of Materials Engineering, Kun Shan University, \\ Tainan 710, Taiwan \\ 3 Department of Chemical Engineering, BV Raju Institute of Technology, Narsapur 502313, Telangana, India; \\ praveen.bvs@bvrit.ac.in \\ 4 Petroleum and Chemical Engineering, Faculty of Engineering, Universiti Teknologi Brunei, \\ Bandar Seri Begawan BE1410, Brunei; manickam.sivakumar@utb.edu.bn \\ * Correspondence: charming@mail.ksu.edu.tw (C.-M.H.); shirish@nitw.ac.in (S.H.S.)
}

Citation: Potdar, S.B.; Huang, C.-M.; Praveen, B.; Manickam, S.; Sonawane, S.H. Highly Photoactive Titanium Dioxide Supported Platinum Catalyst: Synthesis Using Cleaner Ultrasound Approach. Catalysts 2022, 12, 78.

https: / /doi.org/10.3390/ catal12010078

Academic Editor: Didier Robert

Received: 14 December 2021 Accepted: 29 December 2021 Published: 11 January 2022

Publisher's Note: MDPI stays neutral with regard to jurisdictional claims in published maps and institutional affiliations.

Copyright: (C) 2022 by the authors. Licensee MDPI, Basel, Switzerland. This article is an open access article distributed under the terms and conditions of the Creative Commons Attribution (CC BY) license (https:// creativecommons.org/licenses/by/ $4.0 /)$

\begin{abstract}
Catalysts increase reaction rates; however, the surface area to volume ratio of catalysts has a vital role in catalytic activity. The noble metals such as platinum $(\mathrm{Pt})$ and gold $(\mathrm{Au})$ are expensive; despite this, they have proven their existence in catalysis, motivating the synthesis of supported metal catalysts. Metal catalysts need to be highly dispersed onto the support. In this investigation, an ultrasound approach has been attempted to synthesise highly photoactive titanium dioxide $\left(\mathrm{TiO}_{2}\right)$ nanoparticles by the hydrolysis of titanium tetraisopropoxide in an acetone/methanol mixture. To enhance its photocatalytic activity, $\mathrm{TiO}_{2}$ was doped with $\mathrm{Pt}$. The synthesised photocatalyst was characterised by techniques such as particle size analysis (PSA), XRD, FE-SEM, TEM, and EDX. The enhancement in the surface characteristics of Pt-doped $\mathrm{TiO}_{2}$ compared with bare $\mathrm{TiO}_{2}$ support was confirmed with Brunauer-Emmett-Teller (BET) analysis. The enhanced surface area and uniformity in particle size distribution at the nanoscale level were due to the effects of ultrasonic irradiation. The obtained results corroborated the size and composition of the synthesised catalysts. The size of the catalysts is in the nanometre range, and good dispersion of $\mathrm{Pt}$ catalysts over the $\mathrm{TiO}_{2}$ support was observed. The UV-Visible spectroscopy analysis was performed to study the optical properties of the synthesised $\mathrm{TiO}_{2}$ and $\mathrm{Pt} / \mathrm{TiO}_{2}$ photocatalysts. An increase in the absorbance was noted when $\mathrm{Pt}$ was added to $\mathrm{TiO}_{2}$, which is due to the decrease in the band gap energy.
\end{abstract}

Keywords: photocatalyst; ultrasound; titanium dioxide; platinum; photocatalytic activity; nano

\section{Introduction}

Photocatalysis is a technique that harnesses the available abundant solar energy; in it, a photon drives a chemical reaction in the presence of a catalyst. The process is ecofriendly and non-hazardous [1] and is one of the most preferred methods for purifying the pollutants in the atmosphere and aquatic systems [2]. Titanium dioxide $\left(\mathrm{TiO}_{2}\right)$ is a widely used photocatalyst, considering its good catalytic activity, high stability, low cost, and suitable band gap energy [3,4], and hence is beneficial in many applications such as oxidation reactions [5], solar cells [6], hydrogen production [7], water treatment [8,9], and degradation of pollutants [10].

Various dopants are impregnated into $\mathrm{TiO}_{2}$ to extend the sensitivity in the visible spectral range [11]. This process also helps in minimising the surface charge transfer [12]. The metal catalysts doping/impregnation concept has been gaining more importance recently. Here, the primary catalyst is dispersed on a suitable support, obtaining stable nanoparticles (NPs) and reducing costly metal utilisation [13]. Metals used include niobium [6], copper and nickel [7], iron [8], cobalt [12] silver [14], chromium [15], molybdenum [16], 
vanadium [17], silver [18], ruthenium, and platinum [19]. The Schottky barrier formed between $\mathrm{TiO}_{2}$ and metal dopant acts as a source of electron traps or recombination sites to increase the efficiency of $\mathrm{TiO}_{2}$ [20]. Among the above, platinum (Pt) doped $\mathrm{TiO}_{2}$ gives better photocatalytic activity, extending the light absorption to the visible band [21,22]. There are broad-spectrum applications of Pt-doped $\mathrm{TiO}_{2}$, especially in the degradation of dye [23,24], decomposition of phenol [11], and solar energy utilisation [25]. Even though Pt is expensive and has limited commercial usage, it can be compensated for by immobilising suitable supports like $\mathrm{TiO}_{2}$ [25]. Various methods are available for doped $\mathrm{TiO}_{2}$ syntheses, such as sol-gel [26,27], suspension impregnation [28], solid-state reaction [29], sonochemical synthesis [19], and hydrothermal method [30] to manipulate the NPs' shape, size, and other physical properties. In the sonochemical synthesis, the ultrasound-induced chemical effect is attributed to the temperature rise caused by alternating compression and rarefaction cycles of acoustic cavitation. The hot spots are formed due to the rapid formation of the bubbles, their growth and collapse in the liquid media resulting in the metal ions reduction to metals and metal oxides. The sonochemical technique provides local temperatures of more than $5000 \mathrm{~K}$, pressures more than $20 \mathrm{MPa}$, and a very high cooling rate during cavitation bubble collapse, causing special and unique properties for NPs [31].

Very little literature is available for the Pt doped $\mathrm{TiO}_{2} \mathrm{NPs}$ synthesis using the sonochemical method. Teoh et al. [32] reported a one-step $\mathrm{Pt} / \mathrm{TiO}_{2}$ synthesis using a flame spray pyrolysis reactor with controlled crystallite size and surface area. The synthesised particles exhibited rutile and anatase phases. Shanmugam and Gedaken [33] reported the synthesis of Pt NPs on mesoporous anatase $\mathrm{TiO}_{2}$ using the ultrasound-assisted polyol reduction method. The obtained particles were in the range of 100 to $200 \mathrm{~nm}$ and were employed for the oxygen reduction reaction. Neppolian et al. [34] reported synthesising Pt, graphene oxide (GO), and $\mathrm{TiO}_{2}$ photocatalyst. Initially, $\mathrm{TiO}_{2}$ particles were synthesised using the $\mathrm{pH}$ swing method. Later, the ultrasound-assisted hydrothermal method was employed to obtain $\mathrm{GO}-\mathrm{TiO}_{2} \mathrm{NPs}$. Graphene oxide was initially dispersed in a water and ethanol solution mixture and sonicated for $2 \mathrm{~h}$, and the required amount of $\mathrm{TiO}_{2}$ was then added. To this known wt $\%$ of $\mathrm{Pt}$ was doped using the photochemical reduction method.

Bedolla et al. [35] synthesised $\mathrm{Pt} / \mathrm{TiO}_{2}$ utilising acid-treated $\mathrm{TiO}_{2}$ dispersed in isopropyl alcohol using a sonicator probe. At the same time, $\mathrm{Pt}$ precursor $\left(\mathrm{H}_{2} \mathrm{PtCl}_{6}\right)$ was sonicated in an ultrasonic bath. The two solutions were mixed, to which sodium borohydride reducing agent was added and subjected to sonication. A black precipitate was formed after sonicating for $20 \mathrm{~min}$. The surface area of the synthesised catalyst from BET analysis is $193 \mathrm{~m}^{2} / \mathrm{g}$. The synthesised particles were used as catalysts in direct methanol fuel cell applications. Abdulrazzak et al. [36] reported the synthesis of Pt-impregnated $\mathrm{TiO}_{2}$ coated on carbon nanotubes using the sonochemical hydration-dehydration method. $\mathrm{TiO}_{2}$ particles were uniformly distributed on the carbon NPs surface, then coated by $\mathrm{Pt}$ NPs. In all the reports, the particle sizes of $\mathrm{Pt} / \mathrm{TiO}_{2}$ synthesised by ultrasound methods are more than $50 \mathrm{~nm}$. By contrast, in this study, the synthesised particles were with the size of $<20 \mathrm{~nm}$.

The available research work done earlier showed that the size of $\mathrm{Pt} / \mathrm{TiO}_{2} \mathrm{NPs}$ is in the range of $50 \mathrm{~nm}$ or more. This study aims to synthesise anatase phase Pt-doped $\mathrm{TiO}_{2} \mathrm{NPs}$ with a particle size less than $20 \mathrm{~nm}$ using an ultrasound approach. The synthesised particles are characterised using transmission electron microscopy and particle size analyser to study the particle size, X-ray diffraction to study the phase structure, BET analysis to study the pore size, and EDS to study the composition. The data obtained are compared with the available literature as and when required.

\section{Results and Discussion}

\subsection{Photocatalytic Activity of $\mathrm{TiO}_{2}$ and $\mathrm{Pt} / \mathrm{TiO}$}

The UV Visible spectroscopy analysis was performed to study the optical properties of the synthesised $\mathrm{TiO}_{2}$ and $\mathrm{Pt} / \mathrm{TiO}_{2}$ photocatalysts. Figure 1 shows the UV-Vis spectroscopy of $\mathrm{TiO}_{2} \mathrm{NPs}$ and Pt-doped $\mathrm{TiO}_{2} \mathrm{NPs}$. The spectra were obtained in the wavelength range 
of 200 to $1100 \mathrm{~nm}$. No changes in the spectral absorbance were observed beyond the wavelength of $400 \mathrm{~nm}$. From Figure 1, strong absorption was observed in the wavelength range below $400 \mathrm{~nm}$. This is due to the band gap absorption of $\mathrm{TiO}_{2}$. An increase in the absorbance has been observed when $\mathrm{Pt}$ is added to $\mathrm{TiO}_{2}$. This is attributed to the decrease in the band gap energy [37]. The band gap energy calculated from the UV spectrum of $\mathrm{TiO}_{2}$ is $3.2 \mathrm{eV}$ [38]. In comparison, the band gap energy for the $\mathrm{Pt} / \mathrm{TiO}_{2}$ decreases to $2.89 \mathrm{eV}$ when $\mathrm{TiO}_{2}$ is doped with platinum. The mechanism for the photocatalytic activity with a decrease in band gap is shown in Figure 2.

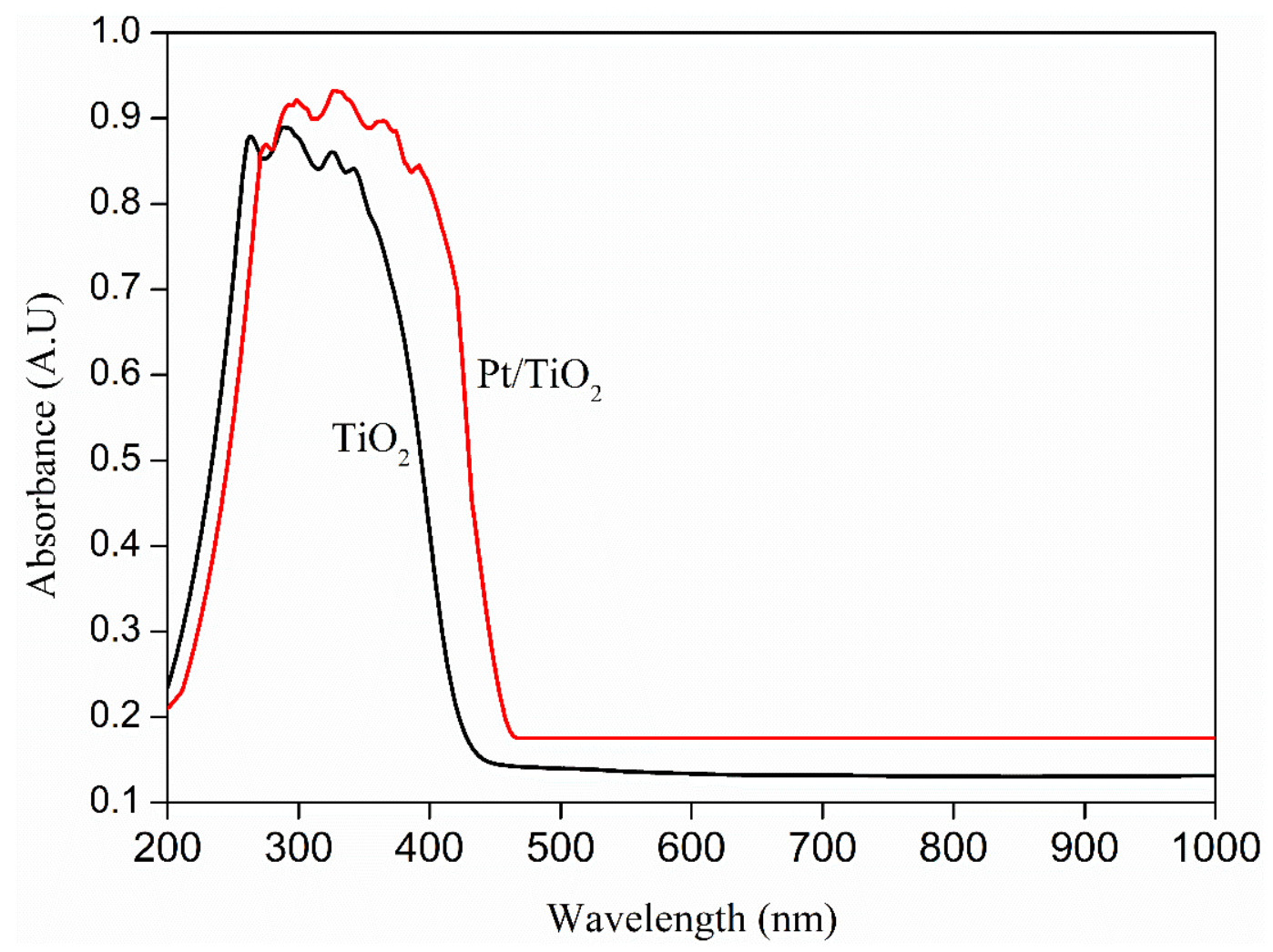

Figure 1. UV-Visible spectra of $\mathrm{TiO}_{2}$ and $\mathrm{Pt} / \mathrm{TiO}_{2}$.

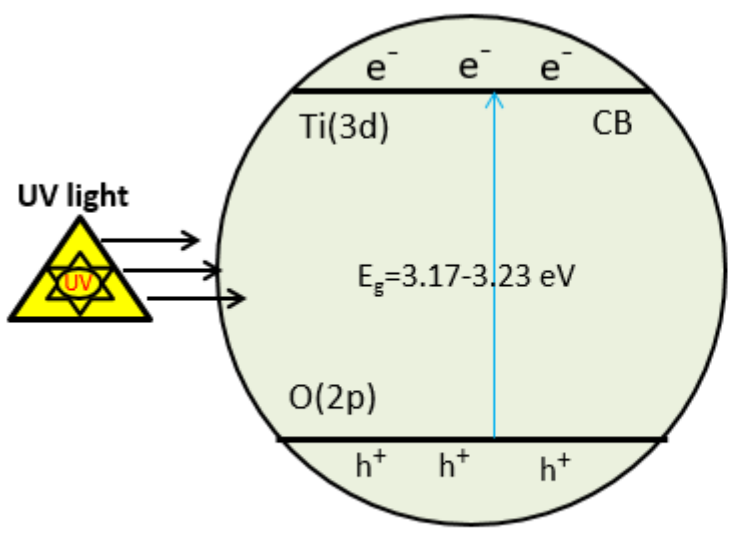

$\mathrm{TiO}_{2}$
Decrease in bandgap of $\mathrm{TiO} 2$ due to doping of $\mathrm{Pt}$

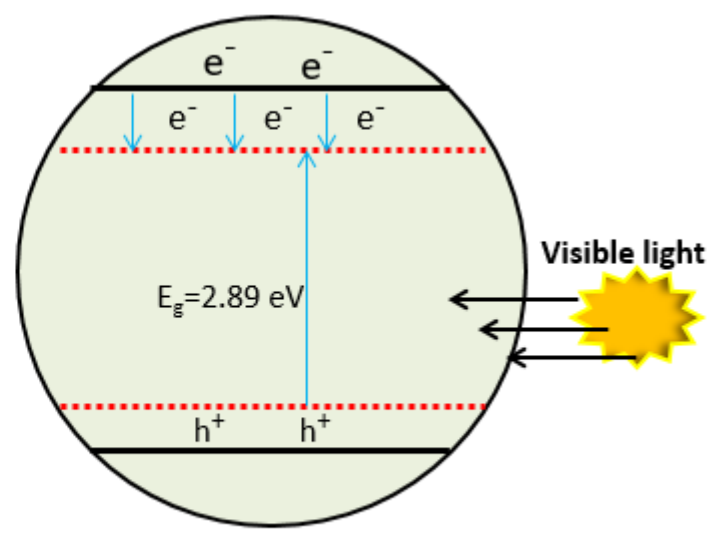

$\mathrm{Pt} / \mathrm{TiO}_{2}$

Figure 2. Mechanism for the contraction in the band gap of $\mathrm{TiO}_{2}$ due to doping with noble metal Pt.

\subsection{Mechanism of Doping of Noble Metal Pt on the Surface of $\mathrm{TiO}_{2}$}

$\mathrm{TiO}_{2}$ NPs function better under UV rays considering their large band gap [39]. However, they suffer from the fast recombination of excited electrons and holes [40]. Hence, 
$\mathrm{TiO}_{2} \mathrm{NPs}$ are modified to be better utilised in the visible range. Figure 2 illustrates the mechanism of the band gap decrease of $\mathrm{TiO}_{2}$ because of the impregnation of Pt. The recombination of the electron-hole pair was reported to be retarded significantly due to the deposition of noble metals such as $\mathrm{Au}$ and $\mathrm{Pt}$ on $\mathrm{TiO}_{2}$. This phenomenon assists in extending the wavelength response to the visible range [41-44].

\subsection{Particle Size Analysis of $\mathrm{TiO}_{2}$ Support and $\mathrm{TiO}_{2}$ Supported Pt Photocatalyst}

Figure 3 shows the particle size obtained from dynamic light scattering analysis for $\mathrm{TiO}_{2}$ and $\mathrm{TiO}_{2}$-supported Pt photocatalyst. Both show a single peak corresponding to uniform particle size distribution. The size distribution of $\mathrm{TiO}_{2}$ support is observed to be between $15 \mathrm{~nm}$ and $120 \mathrm{~nm}$. The average particle size of $\mathrm{TiO}_{2}$ particles is about $37 \mathrm{~nm}$, whereas, in the case of $\mathrm{TiO}_{2}$-supported Pt catalysts, it increased slightly to $43 \mathrm{~nm}$. The particle size analysis facilitates analysing the distribution of the synthesised photocatalyst. However, it failed to give the crystallinity and morphology of the obtained particles. Hence XRD and TEM analyses were employed. The size of the synthesised support and photocatalyst in the nano range $(<50 \mathrm{~nm})$ can be attributed to turbulence and intense shear effects of the ultrasound-induced cavitation.

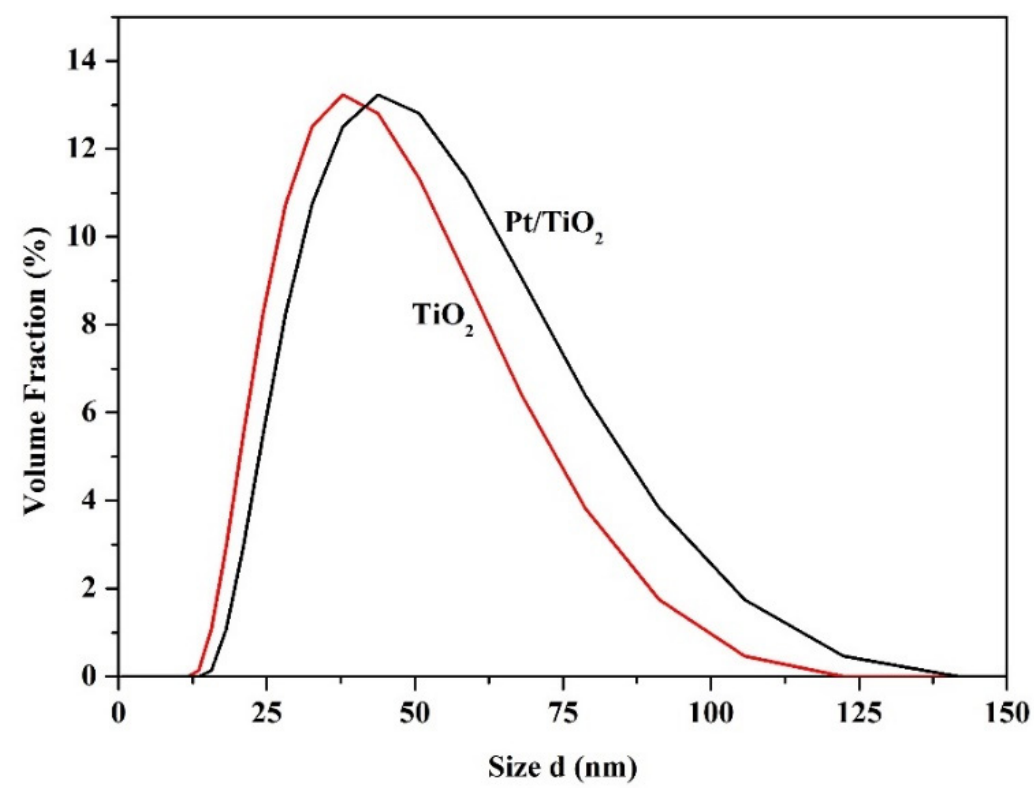

Figure 3. PSA of $\mathrm{TiO}_{2}$ and $\mathrm{TiO}_{2}$ supported Pt catalyst.

\subsection{XRD and BET Analysis of $\mathrm{TiO}_{2}$ Support and $\mathrm{TiO}_{2}$ Supported Pt Photocatalyst}

Figure 4 depicts the XRD spectra of pure $\mathrm{TiO}_{2}$ and Pt-doped $\mathrm{TiO}_{2} \mathrm{NPs}$, and the peaks at $2 \theta$ values of $25.3,37.85,48.01,55.03,62.66$, and 70.06 for $\mathrm{TiO}_{2}$ and $\mathrm{Pt} / \mathrm{TiO}_{2}$ could be observed. Both the XRD spectrum of $\mathrm{TiO}_{2}$ supported $\mathrm{Pt}$ and $\mathrm{TiO}_{2}$ are identical. The lack of any diffraction peak of $\mathrm{Pt}$ on the $\mathrm{Pt}$-doped $\mathrm{TiO}_{2}$ catalyst reveals that $\mathrm{Pt}$ is well dispersed and in smaller quantities. Sharp peaks for $\mathrm{TiO}_{2}$ demonstrate the strong crystalline nature of the particles [45]. However, compared to $\mathrm{TiO}_{2}$, slight peak broadening could be observed in the case of Pt-impregnated $\mathrm{TiO}_{2}$. This might be due to the presence of $\mathrm{Pt}$ on the surface of $\mathrm{TiO}_{2}$ NPs. The crystallite size of $\mathrm{TiO}_{2}$ NPs, calculated using Scherrer's formula, is $10.132 \mathrm{~nm}$, whereas, for the $\mathrm{TiO}_{2}$ supported Pt catalyst, it increased to $13.43 \mathrm{~nm}$. The increase of the average particle size of $\mathrm{TiO}_{2}$ by doping with $\mathrm{Pt}$ might be due to the position and inclusion of $\mathrm{Pt}(\mathrm{IV})$ with $\mathrm{Ti}$ (III) in $\mathrm{TiO}_{2}$ lattice. The smaller crystallite size of the NPs is confirmed by the presence of a large BET surface area $\left(129 \mathrm{~m}^{2} / \mathrm{g}\right)$. The surface characterisation of $\mathrm{TiO}_{2}$ and $\mathrm{Pt} / \mathrm{TiO}_{2}$ was evaluated with Brunauer-Emmet-Teller (BET) analysis in Figure 5, and the outcomes are reported in Table 1 . The specific surface area of $\mathrm{TiO}_{2} \mathrm{NPs}$ is calculated as $71 \mathrm{~m}^{2} / \mathrm{g}$. Interestingly, with the $\mathrm{Pt}$ doping on $\mathrm{TiO}_{2}$, an enhancement in the specific surface area could be noticed, which is in line with the earlier observation [46]. 


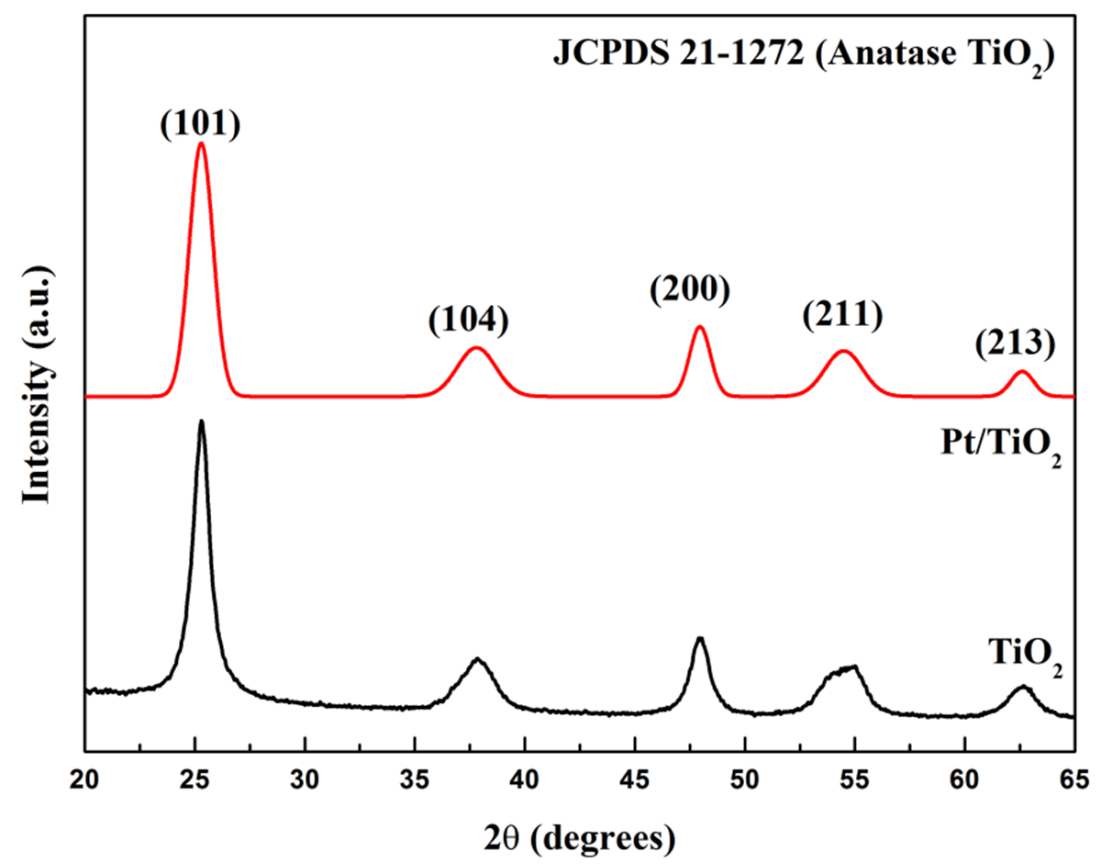

Figure 4. $\mathrm{XRD}$ spectrum of $\mathrm{TiO}_{2}$ and $\mathrm{TiO}_{2}$-supported Pt photocatalyst.

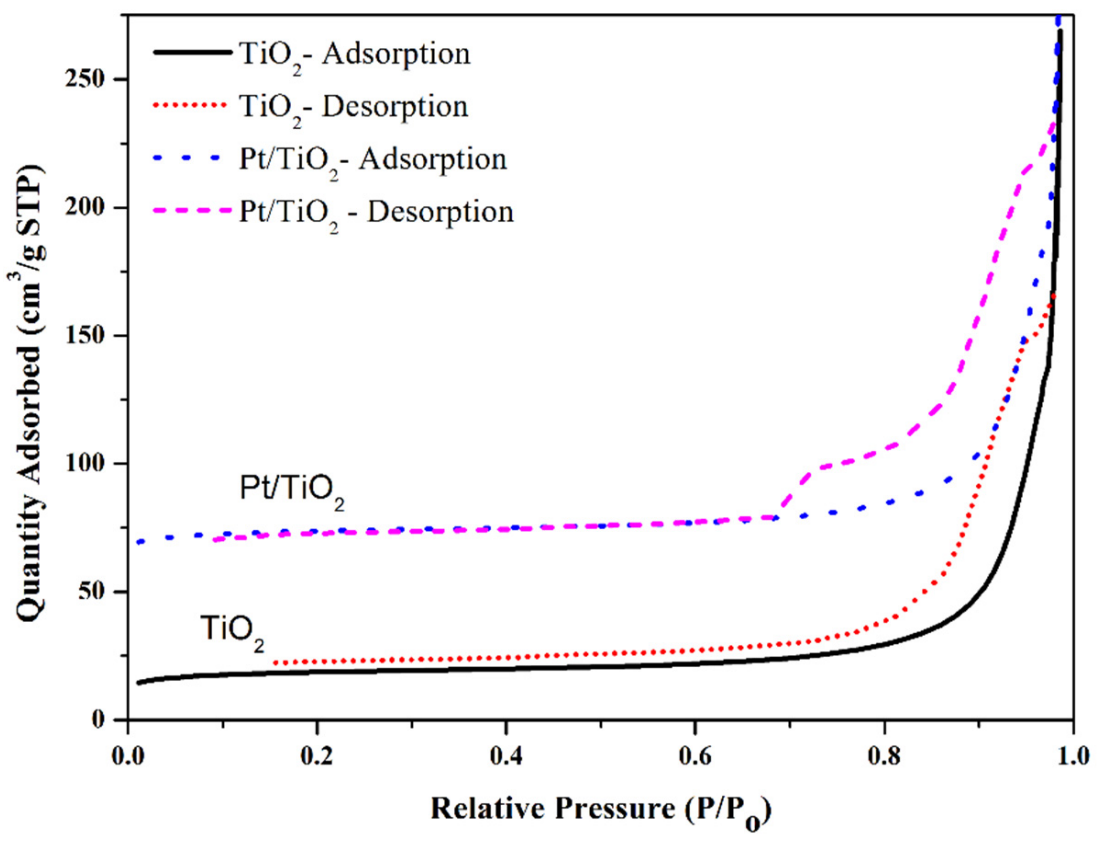

Figure 5. BET specific surface area of $\mathrm{TiO}_{2}$ and $\mathrm{Pt} / \mathrm{TiO}_{2}$.

Table 1. Brunauer-Emmett-Teller (BET) analysis for the particle size and crystallite size: $\mathrm{TiO}_{2}, \mathrm{Pt} / \mathrm{TiO}_{2}$.

\begin{tabular}{|c|c|c|c|c|c|}
\hline $\begin{array}{l}\text { Activated } \\
\text { Carbon }\end{array}$ & $\begin{array}{l}\text { Surface Area } \\
\qquad\left(\mathrm{m}^{2} / \mathrm{g}\right)\end{array}$ & $\begin{array}{l}\text { Pore Diameter } \\
(\mathrm{nm})\end{array}$ & $\begin{array}{l}\text { Pore Volume } \\
\quad\left(\mathrm{cm}^{3} / \mathrm{g}\right)\end{array}$ & $\begin{array}{l}\text { Particle Size } \\
\text { (TEM) (nm) }\end{array}$ & $\begin{array}{l}\text { Crystallite Size Using } \\
\text { Scherrer Equation (nm) }\end{array}$ \\
\hline $\mathrm{TiO}_{2}$ & 71 & 13.6 & 0.31 & 11 & 10.132 \\
\hline $\mathrm{Pt} / \mathrm{TiO}_{2}$ & 129 & 17.2 & 0.45 & 15 & 13.43 \\
\hline
\end{tabular}

\subsubsection{FE-SEM Analysis of $\mathrm{TiO}_{2}$ and $\mathrm{TiO}_{2}$ Supported Pt Catalyst}

Field emission scanning electron microscopy (FE-SEM) gives the topographical information $(10 \times$ to $300,000 \times)$. In the present synthesis, the particles were characterised with 
a magnification of $50,000 \times$, a scale of $1.0 \mu \mathrm{m}$, and $100,000 \times$ and $500 \mathrm{~nm}$. They have been reported in Figures 6 and 7 for $\mathrm{TiO}_{2}$ and $\mathrm{Pt} / \mathrm{TiO}_{2}$, respectively. FE-SEM analysis (Figure 4) shows that the $\mathrm{TiO}_{2}$ particles are spherical, and $\mathrm{Pt}$ doping on the $\mathrm{TiO}_{2}$ support did not change the morphology significantly (Figure 7). The morphology of Pt photocatalyst with $\mathrm{TiO}_{2}$ support remains spherical.

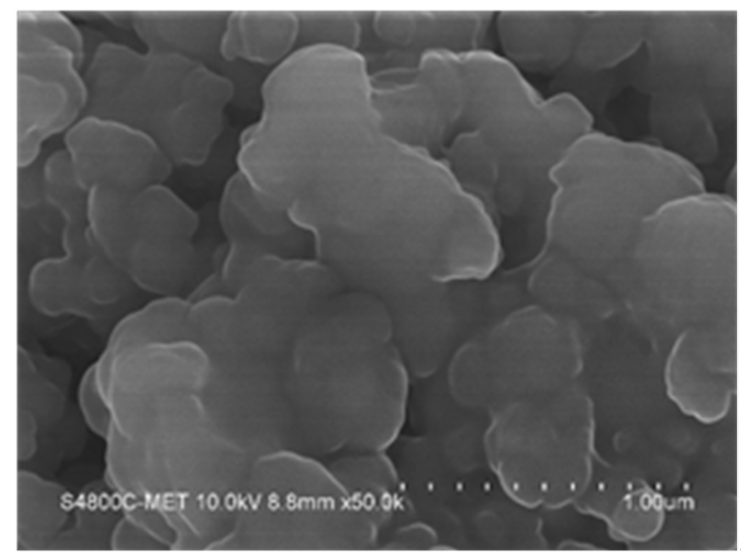

(a)

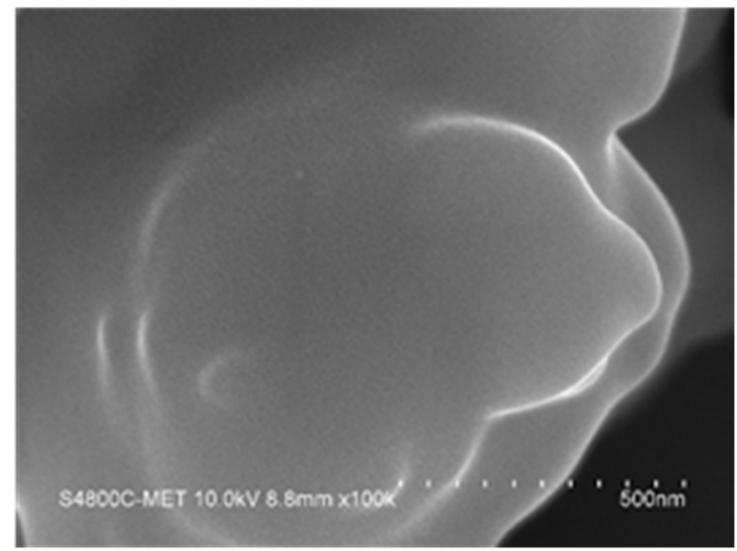

(b)

Figure 6. FESEM images of $\mathrm{TiO}_{2}$ at (a) $1 \mu \mathrm{m}$ (b) $500 \mathrm{~nm}$.

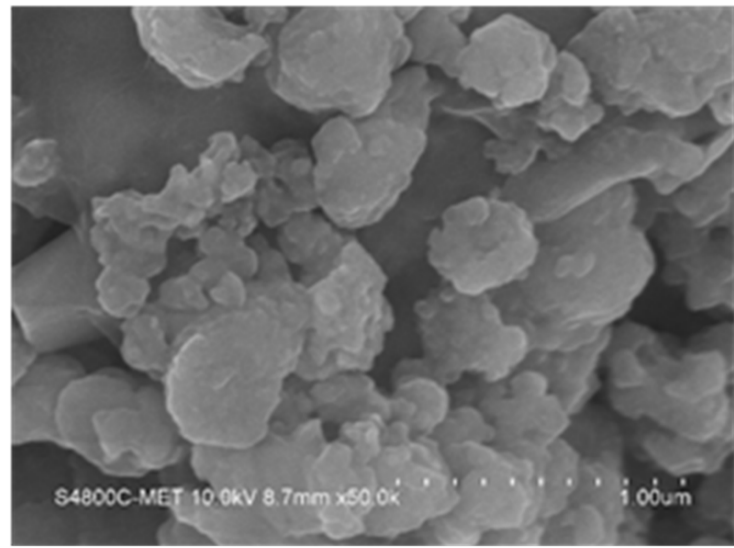

(a)

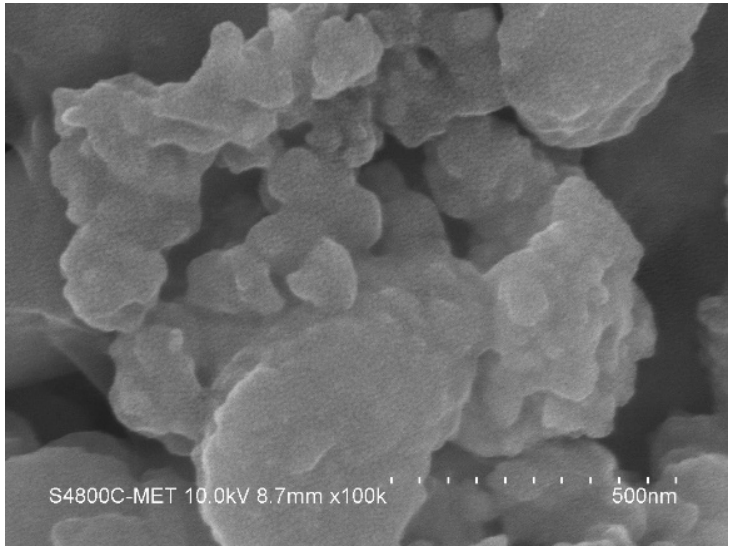

(b)

Figure 7. FESEM images of $\mathrm{Pt} / \mathrm{TiO}_{2}$ at (a) $1 \mu \mathrm{m}$ and (b) $500 \mathrm{~nm}$.

2.4.2. TEM Analysis of $\mathrm{TiO}_{2}$ and $\mathrm{Pt} / \mathrm{TiO}_{2}$

The microjets formed due to ultrasonic cavitation prevent the agglomeration of crystals and result in smaller crystal size and uniform particle size and shape [47]. The TEM images of the $\mathrm{TiO}_{2}$ also confirmed the high degree of dispersion. The images (Figure 8a,b) clearly show that the $\mathrm{Pt}$ catalysts exhibit a uniform distribution over the $\mathrm{TiO}_{2}$ support. $\mathrm{The} \mathrm{Pt} / \mathrm{TiO}$ presents uniform dispersion of $\mathrm{Pt}$ on the $\mathrm{TiO}_{2}$ surface. The mean particle size of pure $\mathrm{TiO}_{2}$ was observed to be between 10 and $12 \mathrm{~nm}$. The average particle size of Pt doped on $\mathrm{TiO}_{2}$ NPs was found to be less than $15 \mathrm{~nm}$ confirming the nanoscale of supported metal catalyst for its photocatalytic effectiveness. The covalent radius of $\mathrm{Pt}$ is $1.30 \AA$, and for $\mathrm{Pt}^{2+}$ and $\mathrm{Pt}^{4+}$, it is 0.80 and $0.65 \AA$, respectively. Titanium has an ionic radius of $0.68 \AA$ in the $\mathrm{Ti}^{4+}$ state. Hence, $\mathrm{Pt}^{4+}$ ion is conveniently inserted into the $\mathrm{TiO}_{2}$. Interestingly, the $\mathrm{Pt}^{4+}$ ions doping does not distort the photocatalyst [48]. 


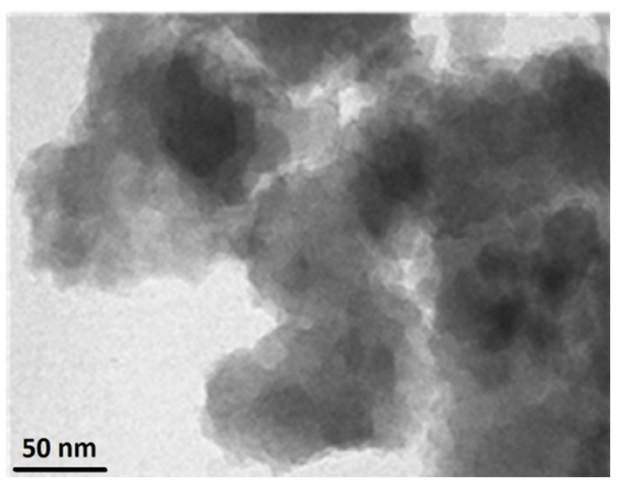

(a)

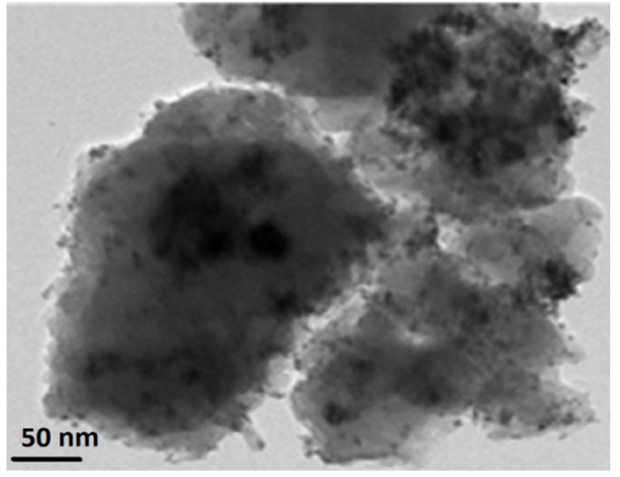

(b)

Figure 8. TEM images (a) $\mathrm{TiO}_{2}$ (b) $\mathrm{TiO}_{2}$ supported Pt catalyst synthesised using acoustic cavitation.

\subsection{Energy Dispersive X-Ray Analysis (EDX) $\left(\mathrm{Pt} / \mathrm{TiO}_{2}\right)$}

Figure 9 depicts the EDX analysis for the $\mathrm{TiO}_{2}$-supported Pt catalyst obtained using ultrasound. The strong peaks of titanium $(41.28 \mathrm{wt} \%)$ and oxygen $(55.51 \mathrm{wt} \%)$ in the spectra indicate that the concentration of support $\left(\mathrm{TiO}_{2}\right)$ is higher compared with Pt catalyst $(3.21 \mathrm{wt} \%)$, as $\mathrm{Pt}$ is an expensive catalyst, and its lower percentage and good dispersion on the support is expected. The chemical composition of $\mathrm{Pt} / \mathrm{TiO}_{2}$ from the EDX analysis is shown in Table 2.

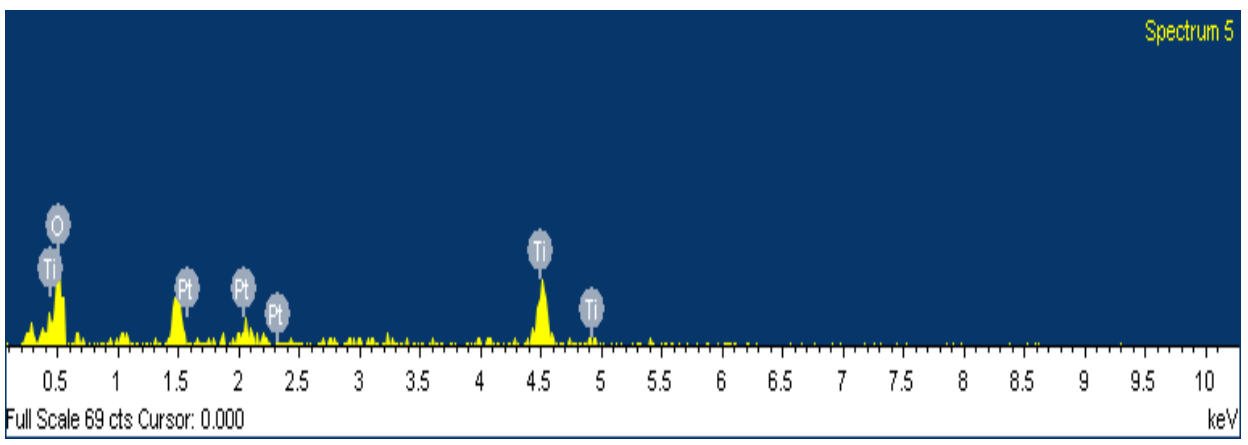

Figure 9. Energy-dispersive $\mathrm{X}$-ray analysis of $\mathrm{Pt} / \mathrm{TiO}_{2}$ photocatalyst.

Table 2. Chemical composition of $\mathrm{Pt} / \mathrm{TiO}_{2}$ determined from EDX analysis.

\begin{tabular}{ccc}
\hline Elements & $\mathbf{W t} \%$ & Atomic $\%$ \\
\hline $\mathrm{O}$ & 73.52 & 90.21 \\
$\mathrm{Ti}$ & 23.03 & 9.44 \\
$\mathrm{Pt}$ & 2.45 & 0.35 \\
\hline
\end{tabular}

\section{Materials and Methods}

\subsection{Materials}

Titanium tetraisopropoxide (TTIP) (97\%) was obtained from Spectrochem Pvt. Ltd. Mumbai, India. Sodium hydroxide (NaOH, 97\%), methanol (HPLC grade), and acetone were obtained from Molychem Ltd., Mumbai, India. Potassium hexachloroplatinate $\left(\mathrm{K}_{2} \mathrm{PtCl}_{6}\right)$ and sodium borohydride $\left(\mathrm{NaBH}_{4}, 98 \%\right)$ were procured from Sainergy fuel cell Pvt. Ltd. Chennai, India.

\subsection{Synthesis of $\mathrm{TiO}_{2}$ as the Support: Ultrasound Approach}

$\mathrm{TiO}_{2}$ NPs were synthesised using an ultrasound approach. To initiate the reaction, TTIP (10 mL) was mixed with acetone and methanol ( $2 \mathrm{~mL}$ each) in a $250 \mathrm{~mL}$ beaker and subjected to sonication. After initial mixing of TTIP, methanol, and acetone, dropwise 
addition of $50 \mathrm{~mL} \mathrm{NaOH}$ was initiated in the presence of ultrasound. The sonicator was operated in batch mode ( $2 \mathrm{~s}$ on and $1 \mathrm{~s}$ off) and was initially carried out for $30 \mathrm{~min}$ and then continued for another $15 \mathrm{~min}$. The extended $15 \mathrm{~min}$ sonication was performed to ensure $100 \%$ conversion of TTIP. The formed white precipitate was filtered, dried, and calcination was carried out at $500{ }^{\circ} \mathrm{C}$ for $4 \mathrm{~h}$. Earlier reports indicate that the calcination of $\mathrm{TiO}_{2} \mathrm{NPs}$ between $600{ }^{\circ} \mathrm{C}$ and $850^{\circ} \mathrm{C}$ lead to either brookite, anatase, or rutile phase [49].

\subsection{Synthesis of $\mathrm{TiO}_{2}$ Supported Pt Catalyst}

For the synthesis of $\mathrm{TiO}_{2}$-supported $\mathrm{Pt}$ photocatalyst, $\mathrm{TiO}_{2}$ support was obtained, as indicated in the previous section. For the doping of Pt catalyst, $70 \mathrm{~mL}$ polyvinyl propylene (PVP) (beaker A) dopant solution was prepared by dissolving PVP (10 mL) in Milli-Q water $(70 \mathrm{~mL})$. From the prepared PVP solution, $10 \mathrm{~mL}$ was taken in another beaker (beaker B), to which $0.5 \mathrm{~g}$ potassium hexachloroplatinate $\left(\mathrm{K}_{2} \mathrm{PtCl}_{6}\right)$ and $0.75 \mathrm{~g} \mathrm{TiO}$ was dissolved. The solution in beaker B was kept under stirring for 6-8 h for proper dispersion. The remaining $60 \mathrm{~mL}$ PVP solution was taken in another beaker (beaker C), to which $0.037 \mathrm{~g}$ sodium borohydride $\left(\mathrm{NaBH}_{4}\right)$ reducing agent was added. The solution in beaker B and beaker $\mathrm{C}$ was mixed and sonicated using an ultrasound probe (Dakshin ultrasonic probe sonicator, frequency $22 \mathrm{kHz}$, with the total power supply of $130 \mathrm{~W}$ ) for $2 \mathrm{~h}$ to ensure the completion of the reaction. Figure 10a shows the synthesis pathway, whereas Figure 10b,c shows the reaction mixture before and after sonication, respectively. The reaction completion was confirmed by the changes in the solution colour (black). The synthesised particles were separated from the solution by centrifugation (9000 rpm and $10^{\circ} \mathrm{C}$ for $12 \mathrm{~min}$ ) and were dried at $150{ }^{\circ} \mathrm{C}$.

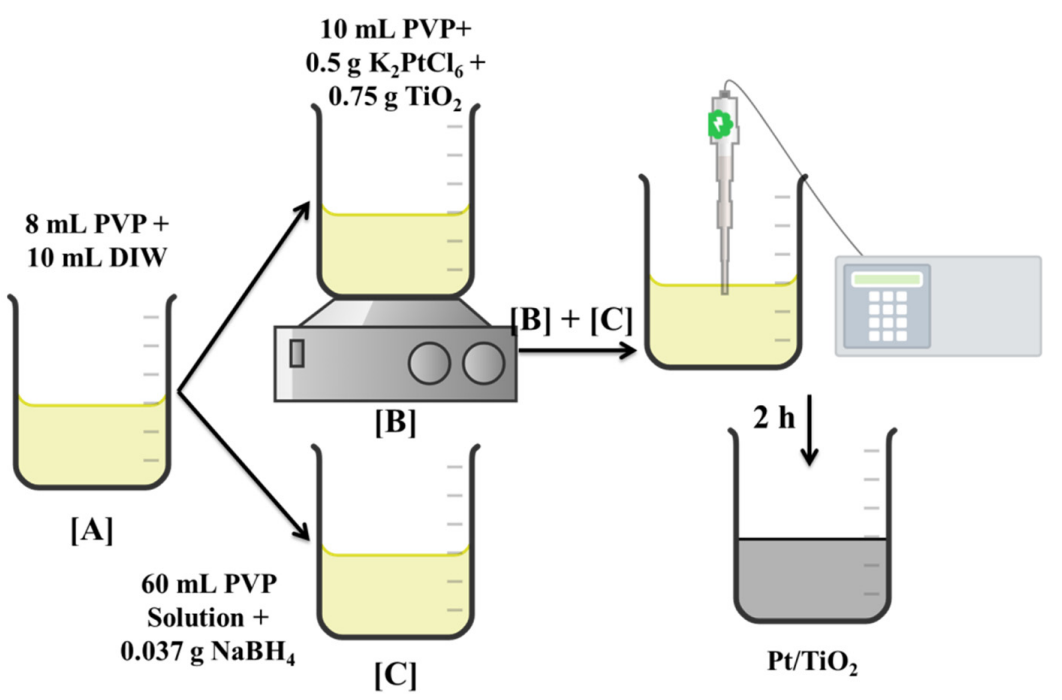

(a)

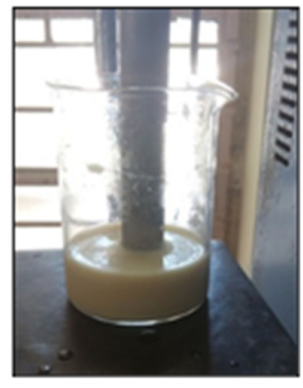

(b)

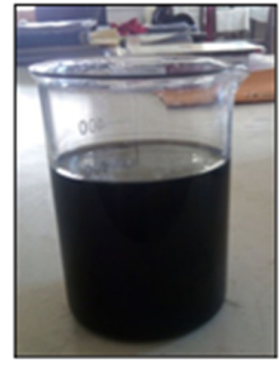

(c)

Figure 10. (a) Synthesis pathway (b) Mixture of $\mathrm{Pt} / \mathrm{TiO}_{2}$ (before reaction) (c) Mixture of $\mathrm{Pt} / \mathrm{TiO}_{2}$ (after reaction). 


\section{Characterisation}

A UV-visible spectrometer (Analytik Jena, PECORD 210 PLUS) was employed to find the band gap energy of the synthesised $\mathrm{TiO}_{2}$ and $\mathrm{Pt} / \mathrm{TiO}_{2}$ particles. The particle size analysis (PSA) of the synthesised support and photocatalyst was carried out using the dynamic light scattering method with Malvern Zetasizer (Nano S90 version 7.02). X-ray diffraction studies were performed to identify the phase and determine the crystallite size of the $\mathrm{TiO}_{2}$ and Pt-doped $\mathrm{TiO}_{2}$. Bruker D8 advanced X-ray diffractometer, operated in reflection mode, was used to record the XRD spectra with $\mathrm{CuK} \alpha$ as the X-ray source with the wavelength of $0.154 \mathrm{~nm}$. The spectra were recorded for $2 \theta$ between $10^{\circ}$ and $90^{\circ}$ with a step size of 0.019 , and the corresponding intensity values were plotted against $2 \theta$ (degree). FE-SEM (TESCAN model Vega 3 LMU) was used primarily to study the surface morphology where the sample was spread over a substrate and analysed. The morphology and size of the synthesised $\mathrm{TiO}_{2}$ support and $\mathrm{TiO}_{2}$-supported Pt photocatalyst were evaluated using FEI-TechnaiTE-20 and JEOL JEM-2100F field emission transmission electron microscope operated at $200 \mathrm{kV}$. The surface characteristics of the support $\mathrm{TiO}_{2}$ and $\mathrm{TiO}_{2}$-supported $\mathrm{Pt}$ catalyst were evaluated through Brunauer-Emmett-Teller (BET) analysis. The nitrogen adsorption-desorption method was used to estimate the particle surface area, pore size and volume. The BET analysis was carried out using the NOVA 1200 (Quantachrome) instrument at $77.3 \mathrm{~K}$. The samples were degassed under vacuum conditions at $353 \mathrm{~K}$ for 4 to $5 \mathrm{~h}$ to remove the adsorbed gases and moisture before the analysis.

\section{Conclusions}

In this study, a photoactive $\mathrm{TiO}_{2}$ catalyst was synthesised with an ultrasound approach to improve the photocatalytic performance of $\mathrm{TiO}_{2}$, and it was doped with a noble metal Pt. The impregnation helps to reduce the band gap and effective utilisation as a photocatalyst in the visible range. The synthesised $\mathrm{TiO}_{2}$ and $\mathrm{Pt}$ impregnated $\mathrm{TiO}_{2}$ photocatalyst exhibit a crystal size of less than $10 \mathrm{~nm}$. The FE-SEM analysis showed that doping Pt onto titanium does not change the morphology. The uniform dispersion of a small quantity of $\mathrm{Pt}$ on the $\mathrm{TiO}_{2}$ support was confirmed using TEM analysis and corroborated by EDX spectra which exhibits a less intense peak of Pt. The nanoscale synthesis is attributed to the intense shear effect arising from ultrasound cavitation. The enhancement in the surface properties of $\mathrm{TiO}_{2}$ due to the addition of $\mathrm{Pt}$ was evaluated in terms of an increase in the surface area of the synthesised photocatalyst. Thus, the ultrasound approach can be considered greener and more energy-efficient for synthesising highly active photocatalysts.

Author Contributions: S.B.P.: contributed to the synthesis, experiments, analysis of data and writing the first draft of the manuscript. C.-M.H.: contributed to data analysis and revising the paper. B.P.: contributed to data interpretation and writing the paper. S.M.: contributed with TEM and BET analysis, writing and revising the paper. S.H.S.: conceived and designed the work and revising the manuscript. All authors have read and agreed to the published version of the manuscript.

Funding: Chao-Ming Huang thanks the funding support by the Ministry of Science and Technology (MOST 110-2637-E-168-002), Taiwan.

Conflicts of Interest: The authors declare no conflict of interest.

\section{References}

1. Schneider, J.; Matsuoka, M.; Takeuchi, M.; Zhang, J.; Horiuchi, Y.; Anpo, M.; Bahnemann, D.W. Understanding TiO 2 Photocatalysis: Mechanisms and Materials. Chem. Rev. 2014, 114, 9919-9986. [CrossRef] [PubMed]

2. Yin, S.; Liu, B.; Zhang, P.; Morikawa, T.; Yamanaka, K.I.; Sato, T. Photocatalytic oxidation of NOx under visible led light irradiation over nitrogen-doped titania particles with iron or platinum loading. J. Phys. Chem. C 2008, 112, 12425-12431. [CrossRef]

3. Sakthivel, S.; Neppolian, B.; Arabindoo, B.; Palanichamy, M.; Murugesan, V. $\mathrm{TiO}_{2}$ catalysed photodegradation of leather dye, Acid Green 16. J. Sci. Ind. Res. 2000, 59, 556-562.

4. Zaleska, A. Doped-TiO ${ }_{2}$ : A Review. Recent Pat. Eng. 2008, 2, 157-164. [CrossRef]

5. Landge, V.K.; Sonawane, S.H.; Chaudhari, R.V.; Babu, G.U.B. Selective Oxidation of Glycerol: A Biomass-Derived Feedstock Using the Pt-Cu Janus Catalyst for Value-Added Products. Ind. Eng. Chem. Res. 2020, 60, 185-195. [CrossRef] 
6. Lü, X.; Mou, X.; Wu, J.; Zhang, D.; Zhang, L.; Huang, F.; Xu, F.; Huang, S. Improved-Performance Dye-Sensitized solar cells using $\mathrm{Nb}$-Doped $\mathrm{TiO}_{2}$ electrodes: Efficient electron Injection and transfer. Adv. Funct. Mater. 2010, 20, 509-515. [CrossRef]

7. Mohamed, N.M.; Bashiri, R.; Chong, F.K.; Sufian, S.; Kakooei, S. Photoelectrochemical behaviour of bimetallic Cu-Ni and monometallic $\mathrm{Cu}, \mathrm{Ni}$ doped $\mathrm{TiO}_{2}$ for hydrogen production. Int. J. Hydrog. Energy 2015, 40, 14031-14038. [CrossRef]

8. Chen, L.; He, S.; He, B.Y.; Wang, T.J.; Su, C.L.; Zhang, C.; Jin, Y. Synthesis of iron-doped titanium oxide nano adsorbent and its adsorption characteristics for fluoride in drinking water. Ind. Eng. Chem. Res. 2012, 51, 13150-13156. [CrossRef]

9. Cheng, T.; Gao, H.; Liu, G.; Pu, Z.; Wang, S.; Yi, Z.; Wu, X.; Yang, H. Preparation of Core-Shell Heterojunction Photocatalysts by Coating CdS Nanoparticles onto Bi4Ti3O12 Hierarchical Microspheres and Their Photocatalytic Removal of Organic Pollutants and Cr(VI) Ions. Colloids Surf. A Physicochem. Eng. Asp. 2022, 633, 127918. [CrossRef]

10. Khalid, N.R.; Majid, A.; Tahir, M.B.; Niaz, N.A.; Khalid, S. Carbonaceous- $\mathrm{TiO}_{2}$ nanomaterials for photocatalytic degradation of pollutants: A review. Ceram. Int. 2017, 43, 14552-14571. [CrossRef]

11. Fernández-Rodríguez, C.; Doña-Rodríguez, J.M.; González-Díaz, O.; Seck, I.; Zerbani, D.; Portillo, D.; Perez-Peña, J. Synthesis of highly photoactive $\mathrm{TiO}_{2}$ and $\mathrm{Pt} / \mathrm{TiO}_{2}$ nanocatalysts for substrate-specific photocatalytic applications. Appl. Catal. B Environ. 2012, 125, 383-389. [CrossRef]

12. Sadanandam, G.; Lalitha, K.; Kumari, V.D.; Shankar, M.V.; Subrahmanyam, M. Cobalt doped $\mathrm{TiO}_{2}$ : A stable and efficient photocatalyst for continuous hydrogen production from glycerol: Water mixtures under solar light irradiation. Int. J. Hydrog. Energy 2013, 38, 9655-9664. [CrossRef]

13. Bagheri, S.; Muhd Julkapli, N.; Bee Abd Hamid, S. Titanium dioxide as a catalyst support in heterogeneous catalysis. Sci. World J. 2014, 2014, 1-21. [CrossRef]

14. Rao, T.N.; Babji, P.; Ahmad, N.; Khan, R.A.; Hassan, I.; Shahzad, S.A.; Husain, F.M. Green synthesis and structural classification of Acacia nilotica mediated-silver doped titanium oxide $\left(\mathrm{Ag} / \mathrm{TiO}_{2}\right)$ spherical nanoparticles: Assessment of its antimicrobial and anticancer activity. Saudi J. Biol. Sci. 2019, 26, 1385-1391. [CrossRef]

15. Ould-Chikh, S.; Proux, O.; Afanasiev, P.; Khrouz, L.; Hedhili, M.N.; Anjum, D.H.; Harb, M.; Geantet, C.; Basset, J.M.; Puzenat, E. Photocatalysis with chromium-doped $\mathrm{TiO}_{2}$ : Bulk and surface doping. ChemSusChem 2014, 7, 1361-1371. [CrossRef]

16. Wang, S.; Bai, L.N.; Sun, H.M.; Jiang, Q.; Lian, J.S. Structure and photocatalytic property of Mo-doped TiO 2 nanoparticles. Powder Technol. 2013, 244, 9-15. [CrossRef]

17. Wu, J.C.S.; Chen, C.H. A visible-light response vanadium-doped titania nanocatalyst by sol-gel method. J. Photochem. Photobiol. A Chem. 2004, 163, 509-515. [CrossRef]

18. Gupta, K.; Singh, R.P.; Pandey, A.; Pandey, A. Photocatalytic antibacterial performance of $\mathrm{TiO}_{2}$ and $\mathrm{Ag}^{-\mathrm{dop}} \mathrm{Ped} \mathrm{TiO}_{2}$ against $S$. aureus. P. aeruginosa and E. coli. Beilstein J. Nanotechnol. 2013, 4, 345-351. [CrossRef]

19. Singh, S.A.; Madras, G. Sonochemical synthesis of $\mathrm{Pt}, \mathrm{Ru}$ doped $\mathrm{TiO}_{2}$ for methane reforming. Appl. Catal. A Gen. 2016, 518, 102-114. [CrossRef]

20. Ihnatiuk, D.; Tossi, C.; Tittonen, I.; Linnik, O. Effect of synthesis conditions of nitrogen and platinum co-doped titania films on the photocatalytic performance under simulated solar light. Catalysts 2020, 10, 1074. [CrossRef]

21. Grabowska, E.; Remita, H.; Zaleska, A. Photocatalytic activity of $\mathrm{TiO}_{2}$ loaded with metal clusters. Physicochem. Probl. Miner. Process. 2010, 45, 29-38.

22. Li, Y.; Li, M.; Xu, P.; Tang, S.; Liu, C. Efficient Photocatalytic Degradation of Acid Orange 7 over N-Doped Ordered Mesoporous Titania on Carbon Fibers under Visible-Light Irradiation Based on Three Synergistic Effects. Appl. Catal. A Gen. 2016, 524, 163-172. [CrossRef]

23. Mohamed, R.M.; Baeissa, E.S. Mordenite encapsulated with $\mathrm{Pt}_{-} \mathrm{TiO}_{2}$ : Characterisation and applications for photocatalytic degradation of direct blue dye. J. Alloys Compd. 2013, 558, 68-72. [CrossRef]

24. Xiong, S.; Yin, Z.; Zhou, Y.; Peng, X.; Yan, W.; Liu, Z.; Zhang, X. The Dual-Frequency (20/40 KHz) Ultrasound Assisted Photocatalysis with the Active Carbon Fiber-Loaded $\mathrm{Fe}^{3+}-\mathrm{TiO}_{2}$ as Photocatalyst for Degradation of Organic Dye. Bull. Korean Chem. Soc. 2013, 34, 3039-3045. [CrossRef]

25. Devipriya, S.P.; Yesodharan, S.; Yesodharan, E.P. Solar photocatalytic removal of chemical and bacterial pollutants from water using $\mathrm{Pt} / \mathrm{TiO}_{2}$-coated ceramic tiles. Int. J. Photoenergy 2012, 2012, 1-8. [CrossRef]

26. Kim, S.; Hwang, S.J.; Choi, W. Visible light active platinum-ion-doped $\mathrm{TiO}_{2}$ photocatalyst. J. Phys. Chem. B 2005, 109, $24260-24267$. [CrossRef] [PubMed]

27. Lin, X.; Li, M.; Li, Y.; Chen, W. Enhancement of the Catalytic Activity of Ordered Mesoporous $\mathrm{TiO}_{2}$ by $\mathrm{Using}^{\mathrm{Carbon}} \mathrm{Fiber}$ Support and Appropriate Evaluation of Synergy between Surface Adsorption and Photocatalysis by Langmuir-Hinshelwood (L-H) Integration Equation. RSC Adv. 2015, 5, 105227-105238. [CrossRef]

28. Rodríguez-Martínez, C.; García-Domínguez, Á.E.; Guerrero-Robles, F.; Saavedra-Díaz, R.O.; Torres-Torres, G.; Felipe, C.; Ojeda-López, R.; Silahua-Pavón, A.; Cervantes-Uribe, A. Synthesis of supported metal nanoparticles $\left(\mathrm{Au} / \mathrm{TiO}_{2}\right)$ by the suspension impregnation method. J. Compos. Sci. 2020, 4, 89. [CrossRef]

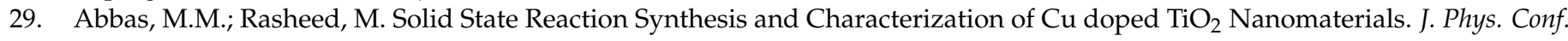
Ser. 2021, 1795, 1-9. [CrossRef]

30. Tang, N.; Li, Y.; Chen, F.; Han, Z. In Situ Fabrication of a Direct Z-Scheme Photocatalyst by Immobilising CdS Quantum Dots in the Channels of Graphene-Hybridized and Supported Mesoporous Titanium Nanocrystals for High Photocatalytic Performance under Visible Light. RSC Adv. 2018, 8, 42233-42245. [CrossRef] 
31. Fan, C.; Chen, C.; Wang, J.; Fu, X.; Ren, Z.; Qian, G.; Wang, Z. Black Hydroxylated Titanium Dioxide Prepared via Ultrasonication with Enhanced Photocatalytic Activity. Sci. Rep. 2015, 5, 1-10. [CrossRef]

32. Teoh, W.Y.; Mädler, L.; Beydoun, D.; Pratsinis, S.E.; Amal, R. Direct (one-step) synthesis of $\mathrm{TiO}_{2}$ and $\mathrm{Pt} / \mathrm{TiO}_{2}$ nanoparticles for photocatalytic mineralisation of sucrose. Chem. Eng. Sci. 2005, 60, 5852-5861. [CrossRef]

33. Shanmugam, S.; Gedanken, A. Synthesis and electrochemical oxygen reduction of platinum nanoparticles supported on mesoporous $\mathrm{TiO}_{2}$. J. Phys. Chem. C 2009, 113, 18707-18712. [CrossRef]

34. Neppolian, B.; Bruno, A.; Bianchi, C.L.; Ashokkumar, M. Graphene oxide based Pt-TiO 2 photocatalyst: Ultrasound assisted synthesis, characterisation and catalytic efficiency. Ultrason. Sonochem. 2012, 19, 9-15. [CrossRef] [PubMed]

35. Bedolla-Valdez, Z.I.; Verde-Gómez, Y.; Valenzuela-Muñiz, A.M.; Gochi-Ponce, Y.; Oropeza-Guzmán, M.T.; Berhault, G.; Alonso-Núñez, G. Sonochemical synthesis and characterization of $\mathrm{Pt} / \mathrm{CNT}, \mathrm{Pt} / \mathrm{TiO}_{2}$, and Pt/CNT/TiO 2 electrocatalysts for methanol electro-oxidation. Electrochim. Acta 2015, 186, 76-84. [CrossRef]

36. Abdulrazzak, F.H.; Hussein, F.H.; Alkaim, A.F.; Ivanova, I.; Emeline, A.V.; Bahnemann, D.W. Sonochemical/hydrationdehydration synthesis of $\mathrm{Pt}_{-} \mathrm{TiO}_{2} \mathrm{NPs} /$ decorated carbon nanotubes with enhanced photocatalytic hydrogen production activity. Photochem. Photobiol. Sci. 2016, 15, 1347-1357. [CrossRef] [PubMed]

37. Driessen, M.D.; Grassian, V.H. Photooxidation of Trichloroethylene on Pt/TiO2. J. Phys. Chem. B. 1997, 102, 1418-1423. [CrossRef]

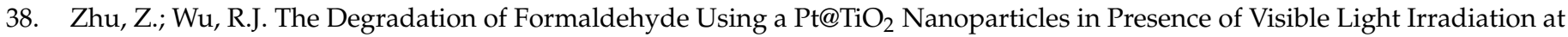
Room Temperature. J. Taiwan Inst. Chem. Eng. 2015, 50, 276-281. [CrossRef]

39. Pinedo-Escobar, J.A.; Fan, J.; Moctezuma, E.; Gomez-Solís, C.; Martinez, C.J.C.; Gracia-Espino, E. Nanoparticulate doubleheterojunction photocatalysts comprising $\mathrm{TiO}_{2}$ (Anatase) $/ \mathrm{WO}_{3} / \mathrm{TiO}_{2}$ (Rutile)with enhanced photocatalytic activity toward the degradation of methyl orange under near-ultraviolet and visible light. ACS Omega 2021, 6, 11840-11848. [CrossRef]

40. Zhao, Z.J.; Hwang, S.H.; Jeon, S.; Hwang, B.; Jung, J.Y.; Lee, J.; Park, S.H.; Jeong, J.H. Three-Dimensional Plasmonic Ag/TiO 2 Nanocomposite Architectures on Flexible Substrates for Visible-Light Photocatalytic Activity. Sci. Rep. 2017, 7, 1-11. [CrossRef]

41. Kim, H.; Choi, Y.; Kanuka, N.; Kinoshita, H.; Nishiyama, T.; Usami, T. Preparation of Pt-loaded TiO 2 nanofibers by electrospinning and their application for WGS reactions. Appl. Catal. A Gen. 2009, 352, 265-270. [CrossRef]

42. Boccuzzi, F.; Chiorino, A.; Manzoli, M.; Andreeva, D.; Tabakova, T.; Ilieva, L.; Iadakiev, V. Gold, silver and copper catalysts supported on $\mathrm{TiO}_{2}$ for pure hydrogen production. Catal. Today 2002, 75, 169-175. [CrossRef]

43. Balachandramohan, J.; Sivasankar, T.; Sivakumar, M. Facile sonochemical synthesis of $\mathrm{Ag}_{2} \mathrm{O}$-guar gum nanocomposite as a visible light photocatalyst for the organic transformation reactions. J. Hazard. Mater. 2020, 385, 121621. [CrossRef] [PubMed]

44. Sivakumar, M.; Towata, A.; Yasui, K.; Tuziuti, T.; Kozuka, T.; Tsujimoto, M.; Zhong, Z.; Iida, Y. Fabrication of nanosized Pt on rutile $\mathrm{TiO}_{2}$ using a standing wave sonochemical reactor (SWSR)-Observation of an enhanced catalytic oxidation of CO. Ultrason. Sonochem. 2010, 17, 213-218. [CrossRef]

45. Ahmed, L.M.; Ivanova, I.; Hussein, F.H.; Bahnemann, D.W. Role of Platinum Deposited on $\mathrm{TiO}_{2}$ in Photocatalytic Methanol Oxidation and Dehydrogenation Reactions. Int. J. Photoenergy 2014, 2014, 1-9. [CrossRef]

46. Abdennouri, M.; Elhalil, A.; Farnane, M.; Tounsadi, H.; Mahjoubi, F.Z.; Elmoubarki, R.; Sadiq, M.; Khamar, L.; Galadi, A.; Baâlala, M.; et al. Photocatalytic degradation of 2,4-D and 2,4-DP herbicides on $\mathrm{Pt} / \mathrm{TiO}_{2}$ nanoparticles. J. Saudi Chem. Soc. 2015, 19, 485-493. [CrossRef]

47. Potdar, S.B.; Praveen, B.V.S.; Sonawane, S.H. Sonochemical approach for synthesis of zinc oxide-poly methyl methacrylate hybrid nanoparticles and its application in corrosion inhibition. Ultrason. Sonochem. 2020, 68, 1-7. [CrossRef]

48. Hong, G.B.; Ma, C.M. Photocatalytic degradation of indoor air pollutants by Pt-TiÖ. J. Nanomater. 2012, 2012, 88-92. [CrossRef]

49. Bethi, B.; Sonawane, S.H.; Rohit, G.S.; Holkar, C.R.; Pinjari, D.V.; Bhanvase, B.A.; Pandit, A.B. Investigation of TiO 2 photocatalyst performance for decolorisation in the presence of hydrodynamic cavitation as hybrid AOP. Ultrason. Sonochem. 2016, 28, 150-160. [CrossRef] 